Radosław Kossakowski, Uniwersytet Gdański

Dominik Antonowicz, Tomasz Szlendak

Uniwersytet Mikołaja Kopernika

https://doi.org/10.18778/1733-8069.8.3.01

\section{Duszący dym odpalonych rac. O wyzwaniach w etnografii subkultury kibiców piłkarskich}

Abstrakt Artykuł traktuje o perypetiach etnograficznych, czyli kłopotliwych sytuacjach terenowych, dylematach metodologicznych, etycznych i technicznych w toku eksploracji świata zaangażowanych kibiców holenderskiej drużyny piłkarskiej FC Twente Enschede. Z myśla o usprawnieniu działań badaczy podejmujących w przyszłości podobnie niełatwe zadania etnograficzne wskazuje się tu wielowymiarowe konsekwencje badania subkultury kibiców piłkarskich. Narracja zogniskowana jest na czterech kwestiach. Pierwsza to trudności z akcesem do wspólnoty kibiców piłkarskich. Druga to niebezpieczeństwa (fizyczne, emocjonalne i prawne) związane z doświadczaniem wspólnoty meczowej i pozameczowej. Kwestia trzecia to konsekwencje tak radykalnej etnografii dla tożsamości badacza, wynikające z prowadzenia badań w trybie „pełnego zanurzenia”. Kwestia czwarta to wpływ trzech pierwszych trudności (uzyskiwania dostępu do zamkniętej grupy, niebezpieczeństw pełnego zaangażowania w działania grupy i przemian w obrębie tożsamości „zanurzonego") na wewnętrzną trafność i zewnętrzną rzetelność opisu etnograficznego.

Słowa kluczowe kibice, obserwacja uczestniczạca, doświadczanie, liminalność

Radosław Kossakowski, dr Dominik Antonowicz, adiunkt Tomasz Szlendak, prof., dyrektor socjologii, adiunkt w Instytucie Fi- w Instytucie Socjologii UMK w To- Instytutu Socjologii UMK w Torulozofii, Socjologii i Dziennikarstwa runiu. Zajmuje się m.in. badaniem niu. Zajmuje się socjologią kultury, Uniwersytetu Gdańskiego. Jego za- społecznego fenomenu kibicowania konsumpcji i rodziny oraz psycholointeresowania badawcze koncentrują oraz przemianami we współczesnym gią ewolucyjną. Opublikował m.in. się na socjologii sportu, społecznym sporcie. Jest współautorem kilku ar- Architektonikẹromansu (2002), Zaniedbafenomenie kibicowania, kulturze tykułów poświęconych kibicowaniu, na piaskownice (2003), Supermarketyzakonsumpcji. Autor książek: Diamento- m.in.: Kibice jako wspólnota niewwidzial- cję (2004) i Socjologię rodziny (2010). Jest wa Droga (2010) i Budda w kulturze kon- nej religii (z Łukaszem Wrzesińskim) członkiem redakcji „,Studiów Socjolosumpcii (2011) oraz licznych artykułów oraz Ostatni bastion antykonsumery- gicznych" i członkiem rady naukowej naukowych i popularno-naukowych. zmu? Kibice industrialni w dobie ko- czasopisma „Kultura i Edukacja”. Był

Dane adresowe autora: i peryferyjny kibic jako aborygen. O wy- Polskiej oraz tygodnika „Polityka”. Instytut Filozofii, Socjologii i Dzien- branych spotecznych konsekwencjach Prowadzi - mieszane metodologicznikarstwa Uniwersytetu Gdańskiego ｏmercjalizacji sportu (oba wraz z To- nie - badania nad przemianami oby-

80-952 Gdańsk, ul. Bażyńskiego 4 maszem Szlendakiem i Radosławem czajów, aktywnością kulturalną, seke-mail: radkoss@wp.pl sualnością i jakością życia. ○ównym celem artykułu jest przybliżenie kłoJ potliwych sytuacji terenowych, dylematów metodologicznych, etycznych i technicznych, z którymi może mieć do czynienia badacz stosujący metodę etnograficzną.

Chodzi o perypetie w trakcie jakościowej eksploracji świata trudno dostępnego i rzadko odwiedzanego przez badaczy społecznych - świata kibiców piłkarskich, a konkretnie - zaangażowanych kibiców holenderskiej drużyny piłkarskiej FC Twente Enschede. $Z$ myślą o ewentualnym usprawnieniu działań badaczy podejmujących $\mathrm{w}$ przyszłości podobnie niełatwe zadania etnograficzne wskazujemy tu rozmaite dylematy przed-i pozaterenowe, problemy w samym terenie, a także wielowymiarowe konsekwencje badania subkultury kibiców piłkarskich. Mamy nadzieję, że przedstawione przez nas zdarzenia, zjawiska i stany przyczynią się do pogłębienia refleksji nad procedurami stosowanymi w badaniach jakościowych. Być może tekst okaże się pomocny dla badaczy, którzy podobnych doświadczeń nie mają, a planują wybranie się $w$ nieznane.

Skupiamy się przede wszystkim na czterech kwestiach. Pierwsza to akces do wspólnoty kibiców piłkarskich. Pokazujemy jakich (często ryzykownych i niespodziewanych) zabiegów wymaga uzyskanie dostępu; z problematyką tą związana jest próba zbudowania więzi z grupa kibiców, zdobycia ich zaufania. Kwestia druga to niebezpieczeństwa (fizyczne, emocjonalne i prawne) związane $\mathrm{z}$ byciem $\mathrm{w}$ środ$\mathrm{ku}$. Trzecia kwestia poruszona $\mathrm{w}$ artykule to konsekwencje takiej etnografii dla tożsamości badacza, wynikające $z$ prowadzenia badań $w$ trybie „pełnego zanurzenia” i w stanie „płynięcia z prądem” (konsekwentnego zaangażowania w proces kibicowania). Już w tym miejscu musimy poczynić uwagę, że zwrotu „pełne zanurzenie” nie rozumiemy w takim sen- sie, jak pojmują go chociażby Martyn Hammersley i Paul Atkinson (2000: 112), czyli jako pełnej integracj $\mathrm{z}$ badaną kulturą przy jednoczesnym ukrywaniu roli badacza. Nasze "pełne zanurzenie” oznacza bycie tu i teraz $\mathrm{w}$ sytuacjach, w których byli badani, z wyraźnym zaznaczeniem roli badawczej. Były to zarówno sytuacje, w których nasza rola badaczy nie miała dla badanych specjalnego znaczenia (np. wspólne śpiewanie pieśni, wznoszenie okrzyków, oklaski itp.), jak i chwile, w których stanowiliśmy z badanymi jedno ciało społeczne. Czwarta kwestia to wpływ trzech pierwszych problemów (pozyskiwania akcesu, niebezpieczeństw „zanurzenia” i tożsamości „zanurzonego") na wewnętrzną trafność i zewnętrzną rzetelność (zob. Miles i Huberman 2000: 288-291) opisu etnograficznego.

Badanie tak hermetycznych środowisk danych społeczności oraz ich kultur stanowi dla socjologów, niemal od zarania dyscypliny, nie lada wyzwanie Mówiąc tu o subkulturze, mamy na myśli ekskluzywne grupy, które charakteryzują się specyficzną odmiennością od kulturowego mainstreamu, często sprzeciwem wobec porządku społecznego, innych grup czy norm, czasami sytuujące się gdzieś na marginesie albo nawet $\mathrm{w}$ podziemiu życia społecznego. Nie uważamy jednak, by subkultura kibiców pozostawała poza społeczeństwem, choć bez wątpienia nie akceptuje ona wszystkich przemian, jakim ulega dziś pole ich działania. Kibice piłkarscy, których badaliśmy, charakteryzują się postawą sprzeciwu wyrażającą się w sformułowaniu Against Modern Football. Kibicom industrialnym (por. Antonowicz, Kossakowski, Szlendak 2011), w których szeregi włączyliśmy się $\mathrm{w}$ trakcie badań, nie podobają się przemiany we współczesnym sporcie. Protestują przeciwko coraz liczniejszym restrykcjom ograniczającym paletę dopuszczalnych zachowań na trybunach, a także zawłaszczaniu sportu przez wielkie korporacje. Warto 
dodać, że komercjalizacja sportu zaowocowała pojawieniem się nowego typu kibica-konsumenta. Obie grupy - eufemistycznie rzecz ujmując - nie przepadają za sobą. Industrialni kibice często wyrażają się z pogardą o nowych kibicach, nazywając ich na przykład „piknikami”. Z kolei kibice-konsumenci uznają ultrasów za agresywnych bandytów przeszkadzających w spokojnej kontemplacji widowiska sportowego jako produktu przemysłu emocjonalnego, takiego jak hollywoodzki film czy plenerowy koncert muzycznej megagwiazdy.

Uznajemy, że w przypadku kibiców industrialnych (a zatem kibiców starego typu) warto stosować etykietę „żywej kultury", która oznacza nie tylko fakt bycia specyficzną, odmienną od innych jakością, ale również istnienia kulturowych form aktywności integralnych z egzystencją tej wspólnoty (zob. Hugson, Inglis, Free 2005: 165-166). Jednocześnie świat społeczny kibiców stanowi w naszym odczuciu część naturalnego życia całości późnonowoczesnych społeczeństw - społeczeństw, które charakteryzują się istnieniem najróżniejszych stylów życia. Robert Prus opisał taką sytuację jako „subkulturową mozaikę, która dotyczy wielości subkultur, światów życia lub grupowych afiliacji, które stanowią o zaangażowaniu ludzi w społeczeństwach lub społecznościach w każdym momencie czasu" (Prus 1997 za: Konecki 2010: 25). Jest nam też bliskie podejście Roberta Parka, który uznawał współczesne mu Chicago za mozaikę małych światów. W podobnym duchu uważamy, że nasz przedmiot badań jest częścią szerszej całości, częścią późnonowoczesnego społeczeństwa rozumianego jako federacja subkultur, nawet jeśli przedstawiciele badanej subkultury pasują do Parkowskiego określenia marginal men, czyli osób, które zajmują - niekomfortową - pozycję pomiędzy dwoma światami (światami uczniów i kibiców, pracowników i kibiców, bezrobotnych i kibiców itp.). Nie rozstrzy- gamy tu jaki jest status jakościowy takich osób. Park uznawał (zob. 1928), że osoby "pomiędzy” często są bardziej cywilizowane, mają szersze horyzonty. Patrząc na kibiców przez pryzmat mainstreamowych doniesień medialnych, należałoby uznać, że $\mathrm{w}$ tym przypadku marginal man to raczej ktoś cywilizacyjnie zacofany, barbarzyńca. $W$ naszych analizach odcinamy się od takiego stanowiska i Parkowskie określenie stosujemy wyłącznie $\mathrm{w}$ kontekście opisu ludzi będących "pomiędzy”.

B1, B2, B3: o metodologicznych ramach badania i kłopotach ze statusem badaczy

Do eksploracji wspólnoty kibiców, do ich poznania i zrozumienia użyliśmy etnograficznej techniki obserwacji uczestniczącej w "pełnym zanurzeniu”. Zdecydowaliśmy się wejść w środowisko badanych po to, żeby doświadczyć obrzędów okołomeczowych od środka. Obserwację uczestniczącą rozumiemy jako „proces zdobywania wiedzy w efekcie wystawiania się bądź zaangażowania w codzienne lub rutynowe działania uczestników badanego kontekstu" (Angrosino 2010: 11). Za etnografię zaś uznajemy tutaj „empiryczne i teoretyczne podejście, które poszukuje szczegółowego, holistycznego opisu i analizy kultur, opartych na intensywnej, uczestniczaccej pracy $w$ terenie" (Hugson, Inglis, Free 2005: 159 [tłum. własne]).

Do badań środowiska kibiców piłkarskich przystąpiliśmy w trójkę ${ }^{1}$, przy czym każdy z nas przystępo-

${ }^{1}$ Badania prowadziliśmy w ramach grantu badawczego „,Kibice industrialni i kibice konsumenci. Od ideologii dla pracujących mas do supermarketyzacji widowisk sportowych" finansowa-
nego ze środków Ministerstwa Nauki i Szkolnictwa Wyższego (NN116295138). Dotyczył on komercjalizacji współczesnego sportu i przemian w obrębie kibicowania. Poza obserwacia uczestniczaca poczynań kibiców-ultrasów zaijmowaliśmy się także wywiadami z osobami, które - w różnoraki sposób zajmują się wspó́czesnym futbolem (architektami stadionów menadżerami takich obiektów, szefami i pracownikami klubów itp.). Pierwsze ustalenia oraz założenia koncepcyjne badan odnaleźć można tu: Antonowicz, Kossakowski, Szlendak (2011) i Kossakowski, Antonowicz, Szlendak (w druku).

wał do nich z innej pozycji. Pierwszy z nas (oznaczamy go w tekście jako B1) znał już od pewnego czasu kibiców, sam długo kibicował. Mógł się zatem pochwalić większym szacunkiem badanych i z pewnością pozwalano mu na więcej. Przebył dłuższą drogę, konieczne rytuały, a doświadczenie w kibicowaniu ułatwiało mu przechodzenie kolejnych stopni wtajemniczenia. Drugi badacz (dalej: B2) zaczynał eksplorację subkultury kibiców piłkarskich od zera. Na początku badań terenowych miał niski status, przy czym nie był „skazany na pożarcie” i wchodzenie w grupe po omacku, jako że wprowadzał go w nią (i na swój sposób wtajemniczał) B1. Trzeci badacz (B3) pozostawał z daleka od eksploracji terenowych, sprawując konieczną - teoretyczną, metodologiczną i etyczną - kontrolę nad stopniem „zanurzenia” B1 i B2. Nasze badania terenowe odbyły się czterokrotnie, $w$ tym trzykrotnie była to obserwacja uczestnicząca w wykonaniu dwóch badaczy (B1 i B2), a jeden raz była to obserwacja dokonana tylko przez B1. Po raz pierwszy wspólna obserwacja odbyła się w kwietniu 2010 roku, kiedy braliśmy udział w meczu ligi

\begin{tabular}{|c|c|c|c|}
\hline MECZ & TYP ROZGRYWEK & LOKALIZACJA & D ATA \\
\hline Twente Enschede - Feyenoord Rotterdam & Liga holenderska & Enschede & 18.04 .2010 \\
\hline Inter Mediolan - Twente Enschede & Liga Mistrzów & Mediolan & 24.11 .2010 \\
\hline Twente Enschede - Rubin Kazań & Liga Europejska & Enschede & 24.02 .2011 \\
\hline Twente Enschede - Ajax Amsterdam & Finał Pucharu Holandii & Rotterdam & 08.05 .2011 \\
\hline
\end{tabular}

W literaturze przedmiotu odnaleźć można niezwykle barwne etnografie świata przestępców, bezdomnych, palaczy marihuany, wspólnot religijnych czy kobiet $\mathrm{w}$ grupach motocyklowych (zob. klasyczne studia Szkoły Chicagowskiej, a także np. Becker [2009], Gizińska [2011]). Wspominamy o nich jedynie po to, by pokazać, że socjologowie zapuszczają holenderskiej między FC Twente Enschede a Feyenoordem Rotterdam. Drugi raz spotkaliśmy się z kibicami w listopadzie 2010 roku podczas wyjazdowego meczu w ramach Ligi Mistrzów z Interem Mediolan. Trzeci raz jednemu z nas dane było zobaczyć mecz w Lidze Europy pomiędzy FC Twente a Rubinem Kazań, natomiast czwarty raz udało się nam wejść w środowisko kibiców w maju 2011 roku, kiedy odbyliśmy z nimi podróż z Enschede do Rotterdamu na mecz finałowy Pucharu Holandii z Ajaxem Amsterdam (spotkanie odbyło się na neutralnym obiekcie). Należy podkreślić, że każda z obserwacji była inna i niepowtarzalna, zaś wszystkie razem dały nam pełne spektrum wydarzeń sportowych, związanych po pierwsze $\mathrm{z}$ różnymi typami rozgrywek, w których uczestniczył klub FC Twente Enschede (rozgrywki ligi holenderskiej, Ligi Mistrzów, Ligi Europejskiej oraz rozgrywki o Puchar Holandii), a po drugie z rozmaitymi lokalizacjami (mecze u siebie, na wyjeździe oraz Finał Pucharu Holandii rozgrywany na neutralnym gruncie). nujące grupy społeczne. Poszerzają wtedy wachlarz socjologicznych doświadczeń, rozbudowują wiedzę socjologiczną o kolejne piętra (czy subpiętra) rzeczywistości społecznej. Dzieje się tak tym bardziej, że - jak zauważa Howard S. Becker - w przypadku obserwacji uczestniczącej mamy do czynienia 
nie tylko z testowaniem hipotez, ale również z ich odkrywaniem (1958: 653). W rezultacie zatem, a nie zawsze bywa to konsekwencją zamierzona, tego rodzaju badania mogą dekonstruować stereotypy i modyfikować obrazy ukonstytuowane przez media. Uczeni nierzadko wychodzą z takich eksploracji inni niż byli przed badaniem. To ostatnie stwierdzenie zapewne wyda się banalne (wszystko bowiem ulega zmianie), chodzi nam jednak o poważną zmianę. Mamy tu bowiem sytuację, w której badacz (często nie mając wyjścia, ale nie zawsze) przekracza pewną granicę $\mathrm{i} w$ procesie badawczym dociera do swoistego stanu liminalnego - właśnie stanu „pomiędzy" byciem badaczem a pozycją tak zwanego nativea. Innymi słowy, chcemy pokazać kulisy tej liminalności - warsztat prowadzenia badań terenowych wśród najbardziej fanatycznych kibiców, czego integralną częścią jest całkowita nieprzewidywalność sytuacji wraz ze spontanicznością zachowań badanych. Nie badaliśmy oczywiście wszystkich kibiców FC Twente Enschede, a jedynie ich część, najbardziej zagorzałych fanów - grupe Vak-P. Etnografia tej grupy była ogromnym wyzwaniem i testem dla naszego warsztatu badawczego, bowiem obserwacja uczestnicząca odbywała się w sytuacjach mocno niestandardowych, a niekiedy ekstremalnych.

Obserwacja uczestnicząca była jedną z kilku zastosowanych przez nas technik zbierania danych, jednym z filarów kompleksu badawczego, w którego skład, poza obserwacją, weszły wywiady pogłębione z kibicami oraz wtórna analiza dokumentów, analiza treści, między innymi prasy kibicowskiej, nieformalnych wydawnictw poszczególnych grup kibicowskich (fanzinów), kibicowskich stron internetowych oraz transparentów wywieszanych w czasie meczów. Michael Angrosino (zob. 2010:
102) opisuje tak skonstruowane badanie etnograficzne jako „dobre”. W naszej analizie pomijamy jednak metodologiczne rozważania związane z przeprowadzaniem wywiadów czy analizą treści, bowiem ich prowadzenie nie odbiegało znacząco od kanonów wyznaczonych w literaturze przedmiotu. Natomiast obserwacja uczestnicząca prowadzona $\mathrm{w}$ warunkach skrajnych emocji jest $\mathrm{w}$ zasadzie niedostępna dla przeciętnego badacza, ogromnie trudna do rzetelnego prowadzenia, a przede wszystkim towarzyszy jej cały szereg niebezpieczeństw fizycznych, metodologicznych oraz etycznych.

Wybór obserwacji uczestniczącej podyktowany był po pierwsze, specyfiką badanej przez nas grupy mającej charakter wspólnotowy, bardzo hermetycznej, a jednocześnie znacząco odbiegającej od kultury dominującej pod względem norm, wartości i zachowań, a po drugie, celem badania, którym było poznanie i próba zrozumienia irracjonalnego, niemal religijnego (według naszych hipotez) świata kibiców, żyjących w stabilnym i bogatym społeczeństwie holenderskim. Socjologowie posiłkują się obserwacją uczestniczącą raczej wtedy, kiedy są szczególnie zainteresowani zrozumieniem specyficznej organizacji lub konkretnego problemu niż demonstrowaniem relacji między abstrakcyjnie definiowanymi zmiennymi (Becker 1958: 652-653). Dlatego przystępując do badań nad kibicami, a szczególnie decydując się na eksplorację grupy najbardziej fanatycznych kibiców holenderskich zrzeszonych w Vak-P, nie mieliśmy w zasadzie innej alternatywy, jeśli prowadzone przez nas badania miały wyjść poza zwykły opis kibicowskiej rzeczywistości widzianej z oddali przy zachowaniu bezpiecznego $\mathrm{dy}$ stansu. Nie sposób bowiem poznać wspólnoty ortodoksyjnych kibiców, obserwując ich zachowania z innych sektorów na stadionie. Bylibyśmy wtedy skazani jedynie na ślizganie się po powierzchni, a nasze zrozumienie zachowań wspólnotowo-stadionowych byłoby powierzchowne. Tymczasem celem naszego badania było wyjście poza „werandową" obserwację i towarzyszący jej powierzchowny opis zachowań dostępnych dla szerszej publiczności. Punktem wyjścia naszych rozważań było przeświadczenie, że zrozumienie fanatycznych kibiców FC Twente Enschede jest możliwe wyłącznie dzięki doświadczeniu interakcyjnemu, które wymaga wejścia do wspólnoty i wspólnego uczestnictwa w kibicowskich rytuałach. Przyjęliśmy zatem postawę wyrosłą z podejścia interakcyjnego, które mówi, że „niezbędne jest wejście do faktycznych sytuacji gdzie żyją «inni», wejście w ich światy życia. Zrozumienie przeżyć innych jest możliwe tylko poprzez ciągłe osiąganie intersubiektywności lub podobnych, jak badani, doświadczeń. Można to osiągnąć poprzez uczestnictwo $\mathrm{w}$ światach życia badanych oraz wielokrotne otwarte z nimi rozmowy" (Konecki 2010: 29). Obserwacja uczestnicząca stała się zatem jednym możliwym narzędziem.

Badacz środowiska kibiców Richard Giulianotti (1995: 2) zauważa, że zastosowanie obserwacji uczestniczącej w takim przypadku łączy się z trzema kwestiami, które w równym stopniu dotyczą socjologów i antropologów kultury. Po pierwsze, jest to opuszczenie przez badacza „komfortowej werandy”, by odnaleźć to, co pojawia się w arkanach innej wspólnoty. Po drugie, istnieje domniemana ciekawość dotycząca szczególnie tych społeczności czy grup, które znacząco różnią się od dominujących $w$ danym kontekście społecznym praktyk i norm (moglibyśmy je nazwać marginal communities). I po trzecie, mamy tu do czynienia z rodzajem empatycznej postawy z badanymi grupami, co skłania również do nieco bardziej relatywizującego podejścia w stosunku do wy- korzystanej wiedzy naukowej, a także społecznych konstrukcji i norm wobec takich zjawisk. Empatia oznacza w tym przypadku uznanie prawdy wyznawanej przez wspólnotę marginalną. Sekunduje jej ostrożność w stosunku do prawd innych dyskursów (medialnych, publicystycznych, a w pewnym zakresie także prawd naukowych).

Owo „zejście z werandy” ma oczywiście nie tylko metaforyczne znaczenie, zawiera $\mathrm{w}$ sobie bowiem również implikacje metodologiczne oznaczające odrzucenie obowiązujących, dominujących (często bardzo popularnych) opinii, stereotypów oraz prawd obiegowych na temat badanej grupy. W przypadku kibiców oznaczało odcięcie się od dominującego w Polsce dyskursu publicznego oraz towarzyszącej mu narracji na temat wspólnoty kibiców (określanych "kibolami” lub „pseudokibicami”). Są one często skutkiem obserwacji „,z werandy” - choćby z pozycji środowisk opiniotwórczych, które wskutek powszechności uznania dla ich sądów mogą być traktowane jako rzetelne i wiarygodne. W naszym przypadku podejście badawcze dobrze opisuje stanowisko getting to know the culture from the perspective of the researched (Hugson, Inglis, Free 2005: 167). Oznaczałoby to bazowanie raczej na dowodach, przekazach z perspektywy emic, a dopiero w dalszej części (np. przy opisie teoretycznym, stanowiącym końcowe działania w procesie badawczym) dodanie naszej perspektywy etic. Uznaliśmy, że aby poznać wspólnotę kibiców, zrozumieć widziany przez nich świat, musimy spojrzeć na nich oczyma ich samych, a nie oczyma policji, ochrony, dziennikarzy, a nawet socjologów gabinetowych (czy raczej „werandowych”). Naszym celem było spojrzenie na świat kibiców bez policyjnych czy dziennikarskich filtrów interpretacyjnych. Sprawiedliwość osądu mogła zatem umożliwić nam jedynie bezpośrednia obserwacja 
uczestnicząca. „W kontekście badawczym oznacza to sprawiedliwe i równe traktowanie uczestników i wszystkich ludzi napotykanych w zasięgu badań" (Hugson, Inglis, Free 2005: 172 [tłum. własne]). Zawieszenie oczekiwań - co rzecz jasna nigdy nie jest do końca skuteczne - mogło się przyczynić do specyficznej przemiany nas jako badaczy. Z drugiej strony chęć ucieczki od patrzenia na badanych wzrokiem wspomnianych „oficjalnych" kategorii nie powinna skłaniać do widzenia kibiców jako ofiar medialnej nagonki, grupy stygmatyzowanej społecznie, noszącej specyficzne piętno wykluczonych (zob. Goffman 2005). Innymi słowy, byliśmy świadomi konieczności uwolnienia się od pułapek narracyjnych dominujących w polskim dyskursie publicznym, ale również uwolnienia się od pokusy nadmiernej empatii wobec badanej grupy (od tzw. underdog sympathy, zob. Hugson, Inglis, Free 2005: 173).

Przed rozpoczęciem pierwszej obserwacji uczestniczącej podczas meczu FC Twente Enschede - Feyenoord Rotterdam zdecydowaliśmy nie strukturalizować naszych obserwacji, podążając za wskazówkami Howarda S. Beckera, który twierdził, że „najlepsze dowody moga być zgromadzone $\mathrm{w}$ trybie najbardziej niewykalkulowanym, kiedy obserwator po prostu zapisuje pozycje, chociaż nie mają one miejsca w systemie koncepcji i hipotez, z którymi w tym czasie pracuje" (1958: 659 [tłum. własne]). Naiwna jest jednak aspiracja prowadzenia badań empirycznych bez żadnej koncepcji dotyczącej natury społeczeństwa i bytów społecznych poddawanych eksploracji. My również mieliśmy pewne idee dotyczące świata kibiców, bowiem projekt badawczy był zbudowany na hipotezach dotyczących komercjalizacji sportu i trybun. Paradoksalną pomocą w naszym przypadku był jednak brak pomocy, a raczej bardzo skromne dziedzictwo polskich badań nad kibicami. Istnie- ja stosowne opracowania (zob. Dudała 2004; Sahaj 2007), ale są to prace nieeksplorujące terenu tak intensywnie, jak etnografia, której się podjęliśmy.

Badania terenowe wymagają od socjologa przyjęcia roli, w której będzie poznawał przedmiot badań. Nie inaczej było $\mathrm{w}$ naszym przypadku. Nie wchodziła $\mathrm{w}$ grę obserwacja niejawna, gdyż w środowisku wspólnotowym, w którym kibice najbardziej zaangażowani wzajemnie się rozpoznają, obecność osób obcych, których przebywania w elitarnym sektorze najbardziej zagorzałych kibiców nikt nie potrafi wytłumaczyć, byłaby źle widziana i niebezpieczna. Nie bylibyśmy w stanie wejść w środowisko badanych tak po prostu. Tak jak obcy człowiek nie wejdzie do naszego domu jako osoba nam bliska (członek rodziny czy przyjaciel), tak my nie mieliśmy szans na to by przyjść w dane miejsce, przywitać się z każdym, a następnie wsiąść do autobusu i ruszyć razem z kibicami na mecz wyjazdowy. Wejście w środowisko wymagało przygotowań, a przede wszystkim jawności, to znaczy przekazania informacji o naszym badawczym pomyśle i zamiarach. Bez wsparcia członków Vak-P ulokowanych wysoko w ich hierarchii prowadzenie badań etnograficznych byłoby niemożliwe $\mathrm{z}$ dwóch zasadniczych powodów. Po pierwsze, bilety uprawniające do wejścia do sektora najbardziej fanatycznych kibiców nie są dostępne dla osób spoza stowarzyszenia kibiców Vak-P. Na te miejsce sprzedaje się wyłącznie sezonowe karnety, których dystrybucja odbywa się przy współpracy klubu z organizacją kibiców. Po drugie, środowisko kibiców jest permanentnie penetrowane przez policję, co powoduje skrajną nieufność wobec obcych osób przebywających w sektorze kibicowskim.

Niedostępność biletów oznaczała w naszym przypadku niemożność nabycia ich drogą oficjalną. Zdobywaliśmy je zatem nieoficjalnie - przy pomocy naszego gatekeepera, któremu z dużym wyprzedzeniem zgłaszaliśmy chęć ich nabycia. Bilety odbieraliśmy kilka godzin przed meczem, nie dociekając oczywiście skąd pochodzą, zawsze jednak płaciliśmy za nie cenę nominalną. W niektórych przypadkach, jak to było przy okazji finału Pucharu Holandii, kilka tygodni wcześniej zostaliśmy zapytani, czy chcemy bilety na finał. $\mathrm{W}$ jednym przypadku (był to nasz pierwszy wyjazd w kwietniu 2010 roku) otrzymaliśmy bilety do innego sektora niż ten dla fanów Vak-P. Jednak kibic, który je nam zorganizował, zapewniał też wejście do sektora najbardziej zaangażowanych kibiców. Wyglądało to w ten sposób, że podszedł z nami do bramy prowadzącej do tego sektora, zaczepił stewarda pilnującego wejścia, a następnie przekazał mu nasze bilety i w sposób szybki, tak by nie rzucać się nikomu w oczy, wprowadził nas za bramę. Była to dla nas duża nobilitacja, ponieważ musiał $\mathrm{w}$ naszym interesie użyć swoich wpływów i kontaktów stadionowych. Do opisania naszej roli badawczej służą rzecz jasna stosowne metafory, które zostały już wcześniej ukute przez badaczy. Bardzo trudno jednak wpisać się nam $\mathrm{w}$ jedną z najpowszechniej stosowanych typologii autorstwa Raymonda Golda (1958). Wynika to po pierwsze z różnego statusu B1 i B2, a po drugie z faktu przemiany naszego statusu w perspektywie czasowej. Zdecydowanie nie byliśmy „obserwatorami nieuczestniczącymi" z powodów, o których pisaliśmy wyżej. W pewnym sensie odpowiednia dla nas była rola „obserwatora jako uczestnika”, która oznacza, że badacz jest osobą znaną w subkulturze badanej, ale odnosi się do niej tylko i wyłącznie jako badacz. Z pewnością była to rola nam najbliższa, gdyż wówczas badacz zawiera bliższe relacje z badanymi, nie rezygnując jednak z neutralności poznawczej. Badania prowadziło zawsze dwóch badaczy (poza jednym wyjątkiem), z których jeden był bardziej obserwatorem niż uczestnikiem, a drug bardziej uczestnikiem (członkiem wspólnoty kibicowskiej) niż obserwatorem. W naszym przypadku nie mogła być brana pod uwagę również druga rola brzegowa, czyli „pełne uczestnictwo”, które oznacza integrowanie się z badanymi na różnym poziomie (członkostwa, emocji itp.), często bez zdradzania, że jest się badaczem. Ta rola nie wchodziła w naszym przypadku w grę, choćby ze względów językowych, kulturowych czy narodowościowych.

Nie oznacza to jednak, że nie mieliśmy możliwości doświadczenia „pełnego zanurzenia”. Przeciwnie, było to możliwe, choć niekoniecznie wiązało się z pełną integracją. Innymi słowy, nasze „pełne zanurzenie" dotyczyło tylko niektórych aspektów uczestnictwa w grupie. Zdajemy sobie sprawę, że może to brzmieć niedorzecznie - trudno sobie wyobrazić, że jest się „zanurzonym” tylko w pewnych „aspektach oceanu". To „,aspektowe zanurzenie” jest w naszym odczuciu charakteryzowane przez pozycję „marginalnego tubylca” (marginal native), którą Gary Armstrong (1993: 20) opisuje jako punkt środkowy między "obcym” (stranger) a "przyjacielem” (friend). Bycie „przyjacielem” oznaczało w naszym przypadku, że zarówno badani, jak i badacze dzielą wspólne zainteresowanie meczem i wydarzeniam na stadionie - atmosferą meczu, wynikiem sportowym, zachowaniem kibiców przeciwnej drużyny. Określenie „obcy” oznacza, że badacz dąży do celów, które nie odnoszą się - ani w kolektywnym, ani w indywidualnym sensie - do członków grupy. Nie trzeba dodawać, że pozostawanie „marginalnym tubylcem" skutkuje swoistymi dylematami. Przykładowo, w trakcie bycia we wspólnocie należy subtelnie dobierać momenty, w których jest możliwe przejście z roli „przyjaciela” do roli „obcego", a w których można na przykład uzyskać dodat- 
kowe informacje. Wiadomo, że nie jest to możliwe w chwili, gdy drużyna zdobędzie bramkę i wszyscy badani wpadną w szał radości. Jednak moment wspólnej podróży na mecz, podróży, która skupia ludzi w jednym miejscu, umożliwia już takie przejście. Była to zresztą chwila, gdy niektórzy z badanych sami chętnie rozmawiali, byli ciekawi naszych spostrzeżeń, chętnie wymieniając się uwagami o zmianach, jakie następują w świecie kibicowskim. Rola „przyjaciela” była bardzo pomocna. Sami interesujemy się sportem, piłką nożną, a zatem materia wspólnego zainteresowania była świetnym punktem wyjścia do rozmów i poszerzania naszej wiedzy. Kibice holenderscy pytali nas często o kibiców polskich. Uznali, że dysponujemy taką wiedzą, a to zawsze generowało porównania, ich komentarze czy nasze pytania o ich sytuację. Wspólne zainteresowania umacniały nasze role insiderów. Jak się potem okazało, wspólne kibicowanie klubowi FC Twente Enschede, które praktykowaliśmy od początku jako obojętni sympatycy, wzmogło nasze wspólne pole doświadczenia, ponieważ w trakcie kibicowania badawczego zaczęliśmy przemieszczać się od roli obserwatora do roli uczestnika, o czym szczegółowo piszemy dalej.

Prowadzenie obserwacji uczestniczącej wśród kibiców FC Twente Enschede nie było wolne od dylematów, na które byliśmy zresztą przygotowani, bowiem mogły one wpływać na ocenę badanych zjawisk, a my sami jako badacze (oraz po prostu ludzie) znaleźliśmy się w sytuacji, którą określa się często mianem double bind. Z jednej strony byliśmy ograniczani przez głęboko zinternalizowane normy społeczne, a z drugiej przez konieczność internalizowania nowych wzorców i norm charakteryzujących subkulturowy świat kibiców. Konieczność kulturowej identyfikacji ze światem, który przynaj- mniej dla jednego z nas (B2) wcześniej był znany właściwie tylko ze źródeł zewnętrznych (doniesienia medialne, książki), spowodowała, że w toku badań musieliśmy się liczyć z nabyciem statusu swoistej marginalności. Warto też podkreślić, że różny poziom „zanurzenia” w subkulturę kibiców powodował, że B1 i B2 proponowali czasem skrajnie odmienne interpretacje tych samych, doświadczanych wspólnie zjawisk. Pokazuje to jak ogromna role odgrywa współczynnik humanistyczny w prowadzeniu obserwacji uczestniczacej, nawet u warsztatowo ukształtowanych socjologów. Dzięki temu, że otaczający nas ludzie nie rozumieli języka polskiego mieliśmy niemal nieustannie możliwość konsultowania między sobą spostrzeżeń, które ilustrowały rozbieżność interpretacji. W jakimś sensie próbowaliśmy zatem, niemal w każdej chwili, budować wspólną definicję sytuacji.

Vak-P otwiera podwoje: procedury wejścia do kibicowskiej wspólnoty

Tytułowe otwarcie należy traktować zarazem dosłownie i metaforycznie - jest to bowiem zezwolenie zarówno na fizyczną obecność, jak i przekroczenie pewnej kulturowej i mentalnej granicy. Wejście do wspólnoty kibiców jest kluczowe dla całego procesu badawczego, a jednocześnie najmniej stabilne, bowiem w każdej chwili członkowie wspólnoty mogą poprosić badaczy o jej natychmiastowe opuszczenie lub (w wersji bardziej radykalnej) fizycznie ich wyrzucić. Takie niebezpieczeństwo istnieje zawsze, ponieważ obecność badaczy nie musi odpowiadać wszystkim członkom wspólnoty, nie muszą ich przyjąć czy nawet akceptować, zwłaszcza że kibice z dużą nieufnością podchodzą do obcych. Już na wstępie stanęliśmy zatem przed wyzwaniem odnalezienia kodu dostępu, czyli zdobycia stosownego zaufania członków grupy.
Nasze wątpliwości potęgował fakt, że uosabialiśmy obcość w kilku wymiarach. Przede wszystkim nie jesteśmy Holendrami i nie mówimy po holendersku. Enschede jest miastem przygranicznym i choć wśród kibiców są również mieszkańcy sąsiadujących regionów niemieckich, to jednak wszyscy oni świetnie mówią po holendersku. Nasza etniczna i kulturowa obcość była dostrzegalna bardziej niż to, że nie byliśmy członkami grupy najbardziej zagorzałych kibiców Vak-P. Naszym medium w kontaktach był język angielski. Mamy świadomość ograniczeń takiej sytuacji. Przede wszystkim ograniczało to naszą zdolność do poznawania językowych struktur charakterystycznych tylko dla badanej subkultury. Pewne zwroty i sformułowania pozostały dla nas nieodgadnione. Sytuacja badawcza rodziła przymus wielokrotnego przekładu. My przekładaliśmy nasze myśli i przekonania z języka polskiego na angielski, a nasi interlokutorzy $z$ holenderskiego na angielski. Z pewnością rodziło to dodatkowe ograniczenia. Nie wszystkie sformułowania da się adekwatnie przełożyć na wspólną, „obiektywną" platformę językową. Po drugie, obie strony porozumiewały się w obcym dla siebie języku, co rodziło specyficzne kłopoty. Doświadczyliśmy tego podczas wywiadów pogłębionych, gdy w przypadku jednego z kibiców musiał mu pomagać kolega, który tłumaczył pytania $\mathrm{z}$ angielskiego na holenderski, a jego odpowiedzi w drugą stronę.

Bariery kulturowe to kolejne trudności, na które napotykaliśmy, podążając szlakiem badawczym. Badając kibiców holenderskich, nie przeżywaliśmy szoku kulturowego jak Bronisław Malinowski czy inni badacze eksplorujący światy zupełnie im obce. Jeżeli w ogóle można w naszym przypadku mówić o szoku kulturowym, to w grę wchodziła raczej kultura kibicowania jako taka - zupełnie odmienna od kultury akademickiej, z którą jesteśmy związani² Holenderska kultura kibicowania jest ponadto wyjątkowa choćby ze względu na powszechność używek w rodzaju marihuany.

W tym kontekście warto przywołać klasyczny esej Georga Simmla (2006: 204-212) - właśnie o „obcym”. Obcym, który choć stawał się członkiem wspólnoty, to nigdy nie był z nią do końca zasymilowany. My tymczasem, na samym początku, nie mogliśmy się legitymować nawet takim statusem. Obcym, który jest zarazem "przyjacielem”, chcieliśmy się dopiero stać. Zastanawialiśmy się, czy etykietka, która przypina się takim kibicom - etykietka folk devils - nie zadziałała na naszą niekorzyść. Przecież badani mogli uznać, że reprezentujemy perspektywę „werandową", która produkuje negatywne etykietki, traktując grupę naznaczoną z wyraźną pogardą. Poza tym chuligańska etykietka, jaką przyczepia się takim grupom, choć byliśmy świadomi jej społecznej konstrukcji, mogła zadziałać niczym samospełniające się proroctwo ${ }^{3}$. Jak uniknąć, już $w$ trakcie

${ }^{2} \mathrm{Na}$ marginesie można dodać, że być może kultura akademicka to take jakas forma subkultury w proponowanym tu rozuosobowości znajdujace sie poza ołównym nurtem i oddające sie poznawaniu bytów, które z codzienną proza życia nie musza mieć wiele wspólnego. Uczeni bywają przecież uznawani za dziwaków. Kto wie, być może czasem subkulturę ludzi nauki (lub jakieś jej części) więcej łączy z innymi subkulturami niż nam się wydaje?

Nalezy zaznaczyć, ze niekiedy kibice przyjmują niektòre etykietki, ktorymi są naznaczani przez inne srodowiska. Podczas analizy treści miesięcznika kibicowskiego "To My Kibice" natrafić można na teksty, ale także zdjęcia ",ekip", które wydaja się utożsamiać z takimi etykietkami, jak np. , "chuliKibice do pewnego stopnia staja sie takimi, jakimi widza ich inni. Wyglada na to, że zewnetrzne pietno staje sie tu źródłem tożsamości i rezerwuarem terminów służących autodefinicji Jest to problem bardzo ciekawy i wart odrębnego potraktowania zarówno $w$ kontekście problematyki jaźni, ale także przez pryzmat koncepcji secondary deviance, kiedy po zaangazzowaniu się $\mathrm{w}$ ",pierwszą dewiację", człowiek przechodz w "dewiację drugiego stopnia", internalizujacc etykietkę dewianta i włączając ją w proces kreowania własnej tożsamośc (zob. np. Lemert 1967). 
wstępnych kontaktów, patrzenia na kibiców przez pryzmat takich etykiet? Jak przekonać holenderskich kibiców, że staramy się bez uprzedzeń zbadać ich świat? Czy nasze tłumaczenia mogą pomóc zdobyć kredyt zaufania u osób, które w ostatnich latach stały się celem bardzo silnych restrykcji ze strony władz państwowych i policji?

Z drugiej strony, jako badacze, musieliśmy odpowiedzieć sobie na pytanie, na co jesteśmy gotowi - w sensie osobowościowym i emocjonalnym w kontaktach z grupa, która jest zdolna do radykalnych zachowań, w której dominuje zbiorowa dusza i trzeba się podporządkować kolektywnym zachowaniom na granicy norm społecznych. Michael Angrosino przed wyjściem $\mathrm{w}$ teren zaleca przeprowadzenie „inwentarza osobowości” badacza (zob. 2010: 66-67). Inwentarz to rodzaj dialogu wewnętrznego, podczas którego badacz sam musi znaleźć odpowiedzi na wiele pytań. Czy jest w stanie wytrwać w specyficznych sytuacjach, do których nie jest przyzwyczajony i które nie były dotychczas areną mechanizmów socjalizacyjnych, jakim był poddawany? Czy jest w stanie popłynąć z prądem sytuacji badawczej, co może skutkować zakwestionowaniem tych Ja przedmiotowych, którymi operował dotychczas? Wchodzenie w role, które dotychczas były nam obce, mogło zakwestionować pewne aspekty naszego Ja, które wydawały się oczywiste. Czy jest w ogóle możliwe wejście $\mathrm{w}$ badanie, przeprowadzenie go, a po zakończonej operacji powrócenie - w wymiarze psychologicznym - do punktu wyjścia? Byliśmy świadomi, że wątpliwości tego rodzaju nie będą nam obce. Być może byłoby nam łatwiej odpowiedzieć na te pytania, gdybyśmy mieli doświadczenia socjalizacyjne w grupie badanej. Nie chodzi tu nawet o bycie jednym z członków grupy Vak-P, ile raczej o bycie kibicem Twente, mieszkań- cem regionu czy miasta Enschede, co bez wątpienia pozwoliłoby nam łatwiej wejść do badanej grupy. Wprawdzie jeden z nas zbudował uprzednio skuteczną sieć kontaktów z kilkoma członkami grupy Vak-P, którzy w nieformalnej hierarchii zajmowali wysokie pozycje, ale były to relacje bardzo osobiste, co niekoniecznie musiało ułatwiać sprawę.

W konsekwencji B1 zaczął próby wejścia do subkultury dużo wcześniej od B2. Kiedy zaczęliśmy badania, „najgorsze” miał już za sobą. Dlatego w tym miejscu rozdzielimy naszą narrację, by dokładnie pokazać, na czym polegała różnica w naszym statusie i z czego wynikała. Wypada nam, dla jasności wywodu, opisać perypetie poszukiwania wejścia do subkultury kibiców dla dwóch badaczy oddzielnie. Pierwszeństwo należy się B1, którego doświadczenia są $w$ tej materii bogatsze, a przede wszystkim wpłynęły na późniejsze badawcze losy B2.

\section{Wchodzi B1}

Pierwsze próby przedostania się B1 do świata kibiców trwały niemal trzy miesiące, na przełomie lat 2007 i 2008, podczas pobytu stypendialnego w Enschede, i nie okazały się skuteczne. Jako człowiek z zewnątrz, kibic kupujący jednorazowe bilety, B1 był skazany na zajmowanie najmniej atrakcyjnego z punktu widzenia celu badań miejsca na stadionie - w sektorze rodzinnym, tuż obok sektora dla kibiców gości. Wprawdzie gwarantowało to dobry widok na sektor Vak-P, ale zajmowane miejsce znajdowało się po przeciwnej stronie stadionu. A zatem, poza dokumentacją fotograficzną, nie umożliwiało dostępu do grupy najbardziej zagorzałych kibiców.

Przełom nastąpił zupełnie przypadkowo. B1 trafił na treningi do lokalnego klubu bokserskiego, który znajdował się w centrum miasta. Bardzo pomógł w tym fakt, że przed wyjazdem stypendialnym B1 trenował amatorsko boks. Szybko okazało się, że wśród trenujących jest wielu kibiców miejscowej drużyny, a byli wśród nich również ci najbardziej fanatyczni, których można było łatwo zidentyfikować. Na ich ciałach znajdowało się wiele rozległych tatuaży klubowych. Poprzez wspólne, regularne treningi relacje B1 z kibicami stawały się coraz lepsze i częstsze.

Dużym krokiem naprzód okazały się mecze wyjazdowe. Wprawdzie początkowo B1 jeździł na nie (po wyrobieniu sobie specjalnej karty) zorganizowanym klubowym transportem z przypadkowymi kibicami, dla których wyjazd był formą turystycznej wycieczki w miłej atmosferze, ale - szczególnie na małych stadionach, takich jak Venlo - nadarzały się okazje, by dać się lepiej poznać najbardziej zagorzałym kibicom. Spotkania wyjazdowe zaowocowały tym, że po którymś z kolei treningu kibice sami złożyli propozycję wspólnego wyjazdu samochodami, co miało być wprawdzie mniej bezpieczne, ale gwarantowało większe emocje. Od tego czasu B1 kilkukrotnie udawał się na mecze wyjazdowe z "ekipa bokserską". Drugim przełomowym momentem było spotkanie z kibicami Feyenoordu Rotterdam, zakończone bójką na jednej ze stacji benzynowych w drodze do Bredy. Wówczas dwunastoosobowa grupa kibiców Twente (w szeregach której był B1) starła się z liczniejszą (około dwudziestoosobową) grupą kibiców Feyenoordu. Konfrontacja nie trwała dłużej niż dziesięć sekund. Jednak, mimo mniejszości liczebnej, żaden z członków „ekipy bokserskiej” nie cofnął się ani na krok, co zostało odebrane jako moralne zwycięstwo. Awantura, która sprowadziła się do symbolicznej wymiany kilku ciosów i kopniaków, znacząco umocniła miejsce B1 w grupie, a także poważnie zwiększyła zaufanie do niego. Od tego czasu status badacza wyraźnie się zmie- nił. Można powiedzieć, że stał się członkiem grupy. Było to widoczne zwłaszcza podczas meczów finałowych rundy play-off, gdy czuć było wyraźnie, że członkowie grupy pilnowali, by się od nich nie oddalać i żeby grupa trzymała się blisko siebie. Co więcej, podczas wspomnianych spotkań z Ajaxem Amsterdam badaczowi z Polski pozwolono podróżować w barwach jego rodzimego klubu żużlowego, co generalnie nie jest akceptowane.

Podsumowując doświadczenia B1, był to długi proces stopniowego wkraczania do grupy, którego przebiegu nie sposób było zaplanować wcześniej, a następnie realizować według planu. Projekt badawczy rozpoczęliśmy zatem, mając już dojście do kibiców FC Twente. Nie było jednak pewne, czy po roku absencji grupa, z którą B1 był związany, zechce przyjąc go $\mathrm{w}$ roli badacza i będzie gotowa pomóc $\mathrm{w}$ organizacji badań, bazując na wcześniejszym zaufaniu. Tym bardziej, że do znanego i zaufanego B1 doszedł B2. Byliśmy ciekawi, jak odniosą się kibice do drugiego badacza. Czy obdarzą go kredytem zaufania, skoro legitymizuje go sprawdzony w boju B1?

\section{Wchodzi B2}

Od początku uznaliśmy, że obserwacja uczestnicząca nie może być prowadzona przez jednego badacza. Różne poziomy zaangażowania kilku badaczy dawały - przynajmniej tak myśleliśmy - szanse na wyrównanie całościowej perspektywy. Dlatego - dla zachowania intersubiektywności obserwacji - uznaliśmy, że zespół badaczy terenowych musi liczyć co najmniej dwie osoby. Wbrew naszym obawom badacze uzyskali werbalną zgodę na przeprowadzenie eksploracji i zapewnienie pomocy w sprawach logistycznych. Już w trakcie pierwszego wspólnego wyjazdu badawczego, na mecz z Feyenoordem w kwietniu 2010 roku, B2 dostał zielone 
światło i mógł zanurzyć się w tłum zgromadzony w sektorze Vak-P. Czyżby zatem wszystko poszło bez najmniejszych problemów, a swoisty ignorant, jakim był B2, otrzymał bilet wstępu bez żadnych zastrzeżeń i na równych zasadach jak B1? Na pierwszy rzut oka mogło się tak wydawać. Okazało się jednak, że - przez dłuższy czas - grupowe statusy B1 i B2 bardzo się od siebie różniły. Większość badanych widziała w B1 bardziej uczestnika (kibica, , ,jednego z nas"), zaś w B2 wyłącznie obserwatora. Różnica w postrzeganiu badaczy przez kibiców uwidaczniała się w sytuacjach „dopuszczania”.

Tak było w Mediolanie, gdzie B2 miał się spotkać z kibicami na głównym placu miejskim Piazza del Duomo, gdzie miano przekazać mu bilety na mecz Ligi Mistrzów z Interem Mediolan. Przebywanie kibiców ubranych w barwy klubowe w środku miasta nie jest sytuacją bezpieczną (kibice konsumują alkohol, śpiewają, klaszczą, choć nie posuwają się do popełniania chuligańskich wybryków i aktów wandalizmu), a przede wszystkim wymaga od kibiców przyjezdnych zachowania całkowitej dyscypliny. Muszą przebywać w większych grupach, ponieważ rozproszeni stają się łatwym celem ataków miejscowych kibiców. Kibice Twente, którzy byli umówieni z B2, przekazali mu bilet, ale nie dopuścili do wspólnego oczekiwania na mecz w centrum Mediolanu. Niewerbalnie dali do zrozumienia, że po przekazaniu biletów każdy powinien pójść w swoją stronę. Nie znaliśmy wtedy powodów tego postępowania, ale nasze intuicyjne przypuszczenia mogliśmy zweryfikować kilka miesięcy później, podczas finału Pucharu Holandii w Rotterdamie. Kibice Twente, z którymi przebywaliśmy, zdecydowali się podjąć ryzykowną misję wymknięcia się z kordonu policyjnego i przedostania do centrum miasta celem wypicia piwa w centralnym barze kibicowskim tego portowego miasta. Uczestnicy „wycieczki” szybko zakamuflowali wszelkie oznaki sympatyzowania ze swym klubem. Wszystkie odkryte tatuaże z logo klubu (a bardzo wielu z nich posiada takie „totemiczne” ozdoby) zostały zakryte odzieżą. My również założyliśmy na siebie bluzy, pod którym ukryliśmy koszulki Twente. „Klubowy uniform” uznaliśmy za ważny atrybut wskazujący naszą identyfikację $\mathrm{z}$ sytuacją. $\mathrm{W}$ centrum miasta nasza grupa podzieliła się na dwie kilkuosobowe grupki żeby nie wzbudzać zainteresowania zarówno kibiców przeciwnika, jak i policji.

Byliśmy wówczas we dwójkę, a to zmieniało postać rzeczy. $\mathrm{B} 1$ był bowiem osobą, która legitymizowała obecność B2 w tym miejscu i czasie, i odpowiadała za zachowanie drugiego badacza, który - mówiąc jezykiem kibiców - nie był jeszcze sprawdzony w akcji. Akcja zakończyła się „zdobyciem” baru. Był to akt odwagi (i, na swój sposób, lekkomyślności), który stał się jednocześnie symbolem zdobycia miasta. Kibice Twente (w tym również my) okazali się bardziej odważni, zuchwali i sprytni, skoro to oni zajęli główny bar kibicowski w Rotterdamie. Wypad ten był niebezpieczny i ryzykowny, gdyż istniało duże prawdopodobieństwo spotkania znienawidzonych kibiców z Amsterdamu lub Rotterdamu4, jak również zwrócenia uwagi patrolujących ulice policjantów. Takie ryzykowne wypady są swoistą formą testowania nowych członków wspólnoty, ich odwagi, solidarności i posłuszeństwa. Fakt, że członkowie ekipy, z którą podróżowaliśmy, nie odrzucili naszej obecności może świadczyć o trzech ewentualnościach. Pierwsza możliwość - w toku badań B2 (obserwator) zyskał zaufanie na tyle, by zezwolono

${ }^{4}$ Swego czasu $\mathrm{w}$ jednym $\mathrm{z}$ barów $\mathrm{w}$ Rotterdamie zginął kibic Twente Enschede. Zdarzyło się to podczas wyjazdowego meczu ze Spartą Rotterdam. Od tego czasu relacje kibicow obu

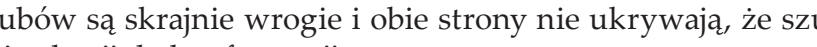
kają okazji do konfrontacji. mu na zerknięcie za kulisy wspólnoty kibicowskiej. Kulisy, za którymi widać, że członkowie wspólnoty poszukują sposobności, aby podnieść sobie poziom adrenaliny. Druga opcja - obecność B1 (uczestnika) była swoistą rękojmią za zachowanie B2 (obserwatora). I po trzecie, i to wydaje się nam najbardziej prawdopodobnym scenariuszem, nastąpił wzrost zaufania do B2. Zaufanie to było dodatkowo wzmocnione obecnością B1, który w razie niebezpiecznej sytuacji bierze odpowiedzialność za kolegę.

Obie te sytuacje - wyjazd do Mediolanu i do Rotterdamu - doskonale ilustrują ewolucję w postrzeganiu badacza przez grupę badanych. To, co zaobserwuje badacz w dużej mierze zależy od tego, jak bardzo wspólnota pozwoli mu się wtajemniczyć. Badacz nigdy nie może być pewien, czy miał dostęp do wszystkich aspektów życia badanej zbiorowości.

Jednak im badacz ma pełniejszą wiedzę o grupie badanych, tym lepiej potrafi ocenić poziom własnego wtajemniczenia.

Przed badaniem zdawaliśmy sobie sprawę, że poszukiwanie ekstremalnych doznań przez ekipy jest częścią świata kibiców, trudno jednak opisać takie zjawiska dopóki samemu nie doświadczy się ich na własnej skórze. W Rotterdamie - na szczęście - nasza „wycieczka po mieście” okazała się spokojna ${ }^{5}$. Nietrudno sobie jednak wyobrazić, że gdyby doszło do spotkania z kibicami Ajaxu lub Feyenoordu, jako badacze mielibyśmy poważny problem etyczny: jak zachować się w takiej sytuacji? Gdybyśmy zdecydowali się pozostać tylko obserwatorami i nie uczestniczyć w konfrontacji, wspólnota prawdopodobnie by nas odrzuciła, stracilibyśmy jej zaufanie i było-

Wśród nas byli kibice, którzy szczycili się tym, że każda ich wizyta w Rotterdamie koriczy się zatrzymaniem przez policje. Można chyba zasadnie uznać, że nasza „wycieczka” była racze
wyjattkiem niż reguła. by trudno o dalszy dostęp do subkultury. Z drugie strony gdybyśmy podjęli walkę, stając się bardziej uczestnikami niż obserwatorami, spotkałyby nas konsekwencje prawne. Takie incydenty w środku miasta rzadko kończą się spokojnym rozejściem się zwaśnionych grup do domów. Ponadto udział $\mathrm{w}$ bójce zawsze wiąże się z niebezpieczeństwem uszkodzeń własnego ciała lub przeciwników. Trzecia opcja zakłada, że jeden z badaczy podjąłby walkę, a drugi obserwował i wówczas nie wiadomo jak zachowałaby się wobec nich badana grupa (trudno zresztą sobie wyobrazić taki scenariusz). W każdym razie trzeba pamiętać, że badacz biorąc udział w obserwacji uczestniczącej, a więc wyrażając chęc zobaczenia tego, czego nie widać z socjologicznej „werandy", musi się liczyć z przejściem od roli obserwatora do uczestnika. Taka możliwość wyłania się z eksploracji świata społecznego, który wymaga coraz intensywniejszej asymilacji.

Wybuchające petardy i gryzący dym: ryzykowna rola „marginalnego tubylca"

Mecz piłkarski jest wyjątkowym wydarzeniem, zwłaszcza jeśli obserwuje się go z sektora dla najbardziej zagorzałych kibiców, którzy w ciągu dziewięćdziesięciu minut ani razu nie siadają na swoich krzesełkach, tylko nieustannie dopingują okrzykami, śpiewem czy rytmicznymi oklaskami. Sama wizyta na stadionie, na którym swe emocje wyraża 40-50 tysięcy widzów, jest intrygująca z socjologicznego punktu widzenia. Dla badaczy świata kibiców sportowy aspekt widowiska jest mało znaczący, choć poziom piłki holenderskiej czy rozgrywek europejskich jest na tyle wysoki, że sprawia przyjemność estetyczną. Naszą uwagę skupiało przede wszystkim to, co się działo na trybunach i w okolicach stadionu, ale również okołomeczowe rytuały 
rozpoczynające się dzień przed meczem (wieczorne spożywanie piwa) i kończące się czasami dzień po meczu, zwłaszcza gdy obejrzenie meczu wymaga odbycia dalekich podróży. Wiąże się to z dodatkowymi niebezpieczeństwami, na jakie narażony jest badacz, którego nie zadowala "werandowa” perspektywa i chciałby spojrzeć na świat kibiców oczyma ich samych.

Dla porządku narracji skupimy się na wyodrębnieniu i omówieniu trzech typów niebezpieczeństw, które w oparciu o nasze doświadczenia mają charakter najbardziej poważnych zagrożeń - fizycznych i psychologicznych. Opiszemy tu także skutki, jakie niesie badanie takiej subkultury dla struktury tożsamości badaczy. Obserwacja uczestnicząca w „pełnym zanurzeniu" oznacza nieustanne niebezpieczeństwo. Przede wszystkim pojawia się ryzyko agresywnego zachowania i konfrontacji z kibicami przeciwnej drużyny, z policją, a w naszym przypadku także z kibicami, którzy nie zechcieliby tolerować naszej obecności. Wspólnota kibicowska składa się z mniejszych grup, które przeważnie są $\mathrm{w}$ bardzo dobrych relacjach, ale zdarzają się odstępstwa od tej reguły. Na szczęście wszystkie te ewentualności okazały się tylko hipotetyczne, choć nie możemy zaprzeczyć, że poczucie niepewności towarzyszyło nam przez cały okres badania. Zwłaszcza że w ewentualnych sytuacjach konfliktowych brak znajomości języka mógłby być dla nas ogromnym problemem.

Poza niebezpieczeństwem awantur czy bójek innym typem niebezpieczeństw, których doświadczyliśmy już osobiście, były materiały pirotechniczne. Petardy dymne i hukowe - choć zabronione na stadionach - pozostają integralną częścią kibicowskich rytuałów. Kontakt z petardami mieliśmy już podczas naszej pierwszej obserwacji w kwietniu 2010 roku. Czekaliśmy wtedy w tłumie kibiców z Vak-P tuż przed stadionem, obok którego znajdował się prowizoryczny bar kibicowski ${ }^{6}$, gdzie odtwarzano bardzo głośną i intensywną muzykę techno (o której w kolejnych akapitach). Pod ścianami znajdowały się nalewaki z piwem, w środku zaś liczna grupa kibiców oddawała się transowej muzyce, wznosząc bojowe okrzyki. Obserwowana sytuacja skojarzyła się nam z rodzajem wspólnotowego hartowania się kibiców, wojowniczym rytuałem, który mentalnie przygotowuje do wyruszenia na wyprawę wojenna. W ramach badań nad fanami piłki nożnej dowiedziono, że kibice o silnej identyfikacji z klubem aprobują używanie wojennych analogii w sporcie. Różnią się w tej materii od fanów o mniejszej identyfikacji (zob. End i in. 2003). Takie samo wrażenie odnieśliśmy $\mathrm{w}$ Enschede. Kibice industrialni wytwarzali intensywną atmosferę wypełnioną muzyką i okrzykami, podczas gdy pozostali kibice (których zalicza się do „pikników”, czyli fanów szukających przede wszystkim indywidualnych wrażen estetycznych płynących z obserwacji wydarzeń na boisku) po prostu przechodzili od kasy do wejść na swoje sektory (ci ostatni również nie wytwarzali atmosfery na stadionie, z rzadka tylko naśladując zachowanie ultrasów, np. robiąc fale) ${ }^{7}$.

Wybuchy petard, race dymne i głośna, ostra muzyka techno powodowały, że czuliśmy się jakbyśmy uczestniczyli w rytuałach plemiennych przed zbliżającą się bitwą. Duże ilości spożywanego przez kibiców alkoholu, którego konsumpcji nie sposób było odmówić, dodawały nam jeszcze odwagi, a kilkusetosobowy tłum kibiców zgrupowanych wo-

${ }^{6}$ Holenderscy kibice często prowadzą swoje bary w okolicach stadionów. Fani druzyny gromadzą się przy nich przed i po cowskie.

"Metaforyka wojenna jest spotykana nie tylko na flagach czy transparentach. Miesięcznik ","o My Kibice!" ma w spisie treści dwie stałe rubryki: „To \& owo na bojowo” oraz "Korespondencja wojenna". kół techno-piwnego namiotu stopniowo wchodził w trans rytmicznych tańców, śpiewów oraz bojowych okrzyków. Przemieszczaliśmy się za naszym gatekeeperem, by nie stracić orientacji i nie znaleźć się w kłopotliwej sytuacji wśród zupełnie nieznanych nam kibiców. Na zewnątrz wszyscy wyśpiewywali kibicowskie pieśni i raczyli się alkoholem (piwo podawano za darmo, a każdy wrzucał datek - co łaska - do talerzyka). Wybuchy petard następowały co kilka minut, bez ostrzeżenia i w różnych miejscach, stając się impulsem do erupcji jeszcze głośniejszych okrzyków i śpiewów. Towarzyszyły temu race dymne. $W$ pewnej chwili jedna $z$ nich wybuchła tuż obok nas, wskutek czego przeżyliśmy lekkie oszotomienie, a w naszych uszach przez dobrych kilka minut wciąż odczuwaliśmy dyskomfort i chwilową, częściową utratę słuchu. Do tego powietrze było przesycone zapachem marihuany. To wszystko tworzyło zupełnie wyjątkową, wspólnotową atmosferę. Jednak zanurzenie $\mathrm{w}$ niej nie było neutralne dla zdrowia badaczy i przyszłych sytuacji, w jakich się znaleźli. Buty B1 były - dla przykładu - do tego stopnia przesiąknięte zapachem marihuany, że w drodze powrotnej, na lotnisku w Monachium, psy szukające narkotyków podjęły trop i badacz został poddany kontroli osobiste

Osobną kwestią są materiały pirotechniczne na stadionie. Oficjalnie ich używanie jest zakazane, ale kibice zawsze przemycają je do swojego sektora. Przeprowadzają zresztą zbiórkę na materiały pirotechniczne przed meczem, do czego - jako członkowie wspólnoty - czuliśmy się zobowiązani dołożyć. Siłę rac poznaliśmy podczas meczu z Feyenoordem w Enschede, a zwłaszcza z Ajaxem w finale Pucharu Holandii w Rotterdamie. W obu przypadkach duszący dym zupełnie ograniczał nie tylko widoczność, ale również utrudniał oddychanie. W pewnym momencie sytuacja stała się bardzo nieprzyjemna, gdyż duża ilość dymu zaczeła bardzo skutecznie przeszkadzać w normalnym oddychaniu. Próbowaliśmy odwracać głowy w nadziei, że dym nie rozprzestrzenia się równomiernie we wszystkie strony Nie było to skuteczne, gdyż wokół nas był tylko dym i pojedyncze osoby, których sylwetki zdołaliśmy dostrzec. Okoliczności były groźne również dlatego, że nie sposób było się przemieścić. Staliśmy w sektorze, w którym kibice byli ściśnięci jak sardynki w puszce. Na nasze szczęście udało się wyrzucić racę poniżej poziomu trybun, co zamknęło drogę do intensywniejszego rozprzestrzeniania się dymu. $\mathrm{Na}$ pamiątkę na białym podkoszulku zostały czerwone plamy (od kolorowego dymu), łzawiące oczy i reakcja naszych płuc w postaci kaszlu. Czerwone plamy wzbudziły zainteresowanie naszych współpasażerów podróży, którzy już przy wyjeździe pytali, czy to nie krew. Warto dodać, że „piro” (tak się mówi na świetlno-dymne atrybuty kibicowania) jest zakazane w większości krajów europejskich (władze poszły na kompromis w Austrii i Norwegii, trwaja rozmowy w Niemczech), choć nasze doświadczenia wskazują na szeroki margines tolerancji dla pirotechniki na stadionach holenderskich.

Wspomnieliśmy o muzyce - głośnej, rytmicznej ścianie dźwięku - towarzyszącej grupie Vak-P. Badania pokazały, że muzyka techno jest wpisana w holenderską kulturę kibicowską. Towarzyszyła nam ona przez cały czas badań. Według naszych obserwacji dynamiczny rytm muzyki techno, wsparty marihuaną i alkoholem, wprowadza kibiców w swoisty trans, którego kontynuacja odbywa się na trybunach (dla najbardziej zagorzałych fanów). Doświadczyliśmy tego nie tylko w namiocie pod stadionem, podczas meczu Twente - Feyenoord (kwiecień 2010), ale przede wszystkim podczas podróży do Rotterdamu na finał Pucharu Holandii w maju 2011 roku. Przez niemal trzy godziny jazdy autobusem z Enschede 
do Rotterdamu towarzyszyła nam ekstremalnie głośna muzyka techno. O gustach muzycznych się nie dyskutuje, ale mimo wszystko po pewnym czasie odczuwaliśmy fizyczny i psychiczny dyskomfort. Kibice bawili się w najlepsze przy ultraszybkich rytmach, które mogły wprawiać w trans, szczególnie, że podróż na miejsce umilano sobie szeroka gamą różnych używek, którymi również nas częstowano. Łącząc umiar obserwatorów z zaangażowaniem badaczy, staraliśmy się zachować trzeźwość umysłu, a jednocześnie nie odbiegać zbytnio od „transowego" klimatu ultrasowskiego autokaru. Używki te królowały również przed stadionem, na który dojechaliśmy trzy godziny przed meczem. Pod trybunami trwało techno-party, na którym bawiło się kilka tysięcy kibiców Twente. Klimat tej imprezy przypominał to, czego wcześniej doświadczyliśmy przed meczami Twente, choć rozmach imprezy był nieporównywalnie większy.

W badania kibiców metodą obserwacji uczestniczącej wpisane jest niebezpieczeństwo utraty zdrowia, podobnie jak jest ono wpisane w samą naturę zaangażowanego kibicowania. Nasze badawcze odczucia wskazują, że ludzie, którzy angażują się w tego typu aktywność, poszukują doznań o charakterze ekstremalnym, a to automatycznie oznacza obcowanie $\mathrm{z}$ ryzykiem. $\mathrm{W}$ parze $\mathrm{z}$ zagrożeniami natury fizycznej szły te związane z psychologią człowieka. Hałas i wystawienie na bardzo głośne dźwięki wzmagały zmęczenie i rozdrażnienie, pojawiał się stres. Ten ostatni jest oczywiście wynikiem niepokoju, który wyrasta w chwilach, w których trudno przewidzieć następstwo zdarzeń. Taka sytuacja związana jest poniekąd z nie do końca komfortową pozycją badacza, który zdany jest na łaskę badanych i z trudem przychodzi mu stawianie granic, które z jednej strony chronią jego osobę (co jest na- turalne w każdej społecznej sytuacji), a z drugiej pozwalają na eksploracje poznawczą. Te granice nigdy nie są do końca ustanowione, stąd metafora „płynięcia z prądem” wydaje się niezwykle adekwatna. W toku badania tego rodzaju subkultury, jaką stanowią najbardziej zaangażowani kibice, przewidywalność zdarzeń nie jest zbyt wysoka. Być może nawet - choć wiemy jak dalece posunięta jest to przenośnia - życie wśród kibiców w roli badacza jest naznaczone klątwą niepewności. Niepewność potęgowała się jeszcze bardziej przez ewentualność właściwie każdego rodzaju zachowania wobec marginal insiders. Niepewność wynika też z jeszcze innej przyczyny. Po badaniach kibiców doszliśmy do wniosku, że tworzą oni niezwykle silnie związaną ze sobą wspólnotę. Są to więzi często wywołujące nieracjonalne decyzje, jak na przykład próby „odbicia" jednego z kolegów z rąk policji, gdy ten został zatrzymany i wsadzony do policyjnego radiowozu. Akt zupełnej desperacji, skazany na niepowodzenie, a dodatkowo skutkujący nieuniknionymi karami, ale najwidoczniej w przypadku takich więzi racjonalne kalkulacje przestają mieć znaczenie.

Z naszych obserwacji wynika, że grupę kibiców łączą więzi durkheimowskiej solidarności mechanicznej, w ramach której dobro wspólnoty góruje nad indywidualnymi interesami poszczególnych członków. Wchodząc do wspólnoty, nawet jako badacz, trzeba być gotowym, że możliwość pozostania z boku, jako jednostki niezaangażowane, jest ograniczona. Na szczęście podczas naszych badawczych eksploracji nie musieliśmy testować naszych grupowych więzi i przez większość czasu mogliśmy pozostawać nieco $\mathrm{z}$ boku, co nie wymagało żadnych dowodów sympatii i poświęcenia. Stwarzało za to komfort badawczego "nurkowania” tylko w tych sytuacjach/ aspektach, które sami uznaliśmy za warte „zanurze- nia". Owszem, zdarzało sie nam przeżyć niezwykłe chwile, gdy tłum zupełnie spontanicznie wyrażał swoje emocje na meczu i kilkanaście tysięcy ludzi zaczęło śpiewać jedną pieśń. Pieśni brzmiały naprawdę potężnie, a ich specyficzna wibracja wydawała się mieć iście rytualny, niemalże religijny charakter. Niemniej, siła naszej lojalności w każdej chwili mogła być wystawiona na próbę i świadomość tego faktu powodowała, że podczas całego okresu obserwacji uczestniczącej pozostawaliśmy w emocjonalnym napięciu i niepewności, które są uczuciami wycieńczającymi psychicznie. Naturalnie, poczucie pewnej obcości czy specyficznej marginalizacji służy temu, by zachować obiektywizm w badaniach, ale jednocześnie wywołuje stres i napięcie, nad którymi trudno przejść do porządku dziennego.

Niestety nie są to jedyne problemy natury emocjonalnej czy psychologicznej. Wielkim wyzwaniem dla badacza jest sprawa zachowań, których w sytuacji niebadawczej nie akceptuje się lub unika. Jednakże w pewnych okolicznościach trudno pozostawać równie ortodoksyjnym, szczególnie gdy prowadzi się obserwację uczestniczącą subkultury, której wartości i normy odbiegają od tych zinternalizowanych przez badacza. Dotyczy to przede wszystkim korzystania z używek - alkoholu i narkotyków. Byliśmy nieustannie częstowani zarówno „twardymi” (kokaina), jak i „miękkimi” narkotykami (marihuana), która w Holandii jest zresztą legalna. $W$ takich sytuacjach - kierując się wewnętrznym żyroskopem etyki - trzeba intuicyjnie wyczuwać akceptowalne zachowania. Trzeba milcząco zaakceptować, że ktoś z nas musiał stać jako „czujka”, podczas gdy niektórzy nasi towarzysze podróży zażywali kokainę. Jako badacze nie mogliśmy pozwolić sobie na oddawanie się narkotycznym transom, a jednocześnie byłoby sztuczne, gdybyśmy pili wyłącznie kawę i jedli crossainty. Zachowanie umiaru i racjonalne podejście do używek pozwoliło nam zachowywać trzeźwość umysłu bez względu na okoliczności. Klimat podróży z kibicami zawiera jednak komponen granicznych doświadczeń i choć nasza gotowość do przekraczania granic świadomości była ograniczona, to nie spotkało się to z żadną formą ostracyzmu. Być może stało się tak dlatego, że wśród wielokulturowej społeczności zaangażowanych kibiców byli również muzułmanie, którzy całkowicie odmawial korzystania z jakikolwiek używek, a grupa tolerowała to bezproblemowo

Jak już wspominaliśmy, istnieje niebezpieczeństwo fizycznej konfrontacji między grupami kibiców różnych klubów. Nie jest to sytuacja częsta, ale bynajmniej nie nadzwyczajna. Awantury na trybunach nie raz były powodem uszczerbku na zdrowiu czy nawet pozbawiały życia. Podczas badań w ramach tego projektu sami tego nie doświadczyliśmy, choć kilkukrotnie otarliśmy się o okoliczności, w których siłowe rozwiązanie sytuacji konfliktowej było bardzo realne.

Są to chwile niezwykle stresujące dla badacza i obecne niemal na każdym meczu wyjazdowym. Atmosfera konfrontacji była wyczuwalna w Mediolanie, chociaż tam $\mathrm{w}$ drodze na stadion poruszaliśmy się bez naszych „znajomych”. Jednak w metrze mieliśmy do czynienia z ożywionym dialogiem dwóch grup fanów Twente i Interu. Dialog był prowadzony w języku angielskim i stąd doskonale wiedzieliśmy, że sytuacja staje się niebezpieczna. Wszystko zakończyło się na słownych przepychankach, być może z tego powodu, że byli to kibice nieortodoksyjn (z pewnością podobna scysja z kibicami znaszej „ekipy" zakończyłaby się solidną awanturą w metrze). Podróżując po obcym mieście z kibicami w barwach klubowych, trzeba się liczyć z niebezpieczeństwem 
być przygotowanym na atak, obserwować innych kibiców, identyfikować zagrożenia. Akty przemocy zawsze się zdarzaja, a świadomość tego rodzi napięcie, które wydawało się narastać w „lukach”, czyli niezabezpieczonych przejściach, terenach przed stadionem czy na ulicach miasta. Należy także pamiętać, że do pokazu siły mogło dojść w starciach z policją, która w konfrontacji z kibicami często stosuje zasadę odpowiedzialności zbiorowej. Dlatego można powiedzieć, że wspomniane problemy - niepokój, poczucie obcości i marginalizacji, wrogość, stres i niepewność - składają się na "syndrom dysadaptacji" (zob. Hammersley, Atkinson 2000: 121). Zniesienie lub pogłębienie tych odczuć zależy od wielu czynników, żeby wymienić dyspozycje osobiste badacza czy stopień, $\mathrm{w}$ jakim badani zmieniają swoje nastawienie do „marginalnego tubylca”.

\section{Doświadczenie - doświadczanie -} "stubylczenie"

Gdy zaczynaliśmy badania, każdy z nas startował z innego poziomu „zanurzenia”. W przypadku B2, który zaczynał od roli „marginalnego insidera”, po „wynurzeniu" można było dostrzec zmianę podejścia to tego tematu, zjawiska i ludzi. B2 początkowo demonstrował sympatię, którą określić można mianem „neutralnej”, czyli takiej, jaką obdarza się większość ludzi, którzy nie są nam bliscy, ale z którymi łączy nas wspólny los. Nie da się ukryć, że ta „neutralna sympatia” przekształciła się z czasem $\mathrm{w}$ „sympatię pozytywną". Ewolucja ta nie dotyczyła stosunku do poszczególnych osób (bo to kwestia indywidualna), ale postawy wobec fenomenu zaangażowanego kibicowania czy całej kibicowskiej subkultury. „Zanurzenie" we wspólnocie kibiców, wejście do grupy pozwala na patrzenie na badanych ich oczyma, czyli nietraktowanie ich z pozycji „werandy", która o kibicach ma na ogół zdanie pejoratyw- ne. Ustanawia to relację między badaczem a badanym na poziomie podmiotowości obu stron. Jest to oczywiście spostrzeżenie nienowe, choć traktowane jako alternatywne w socjologii, o czym przekonuje choćby Anna Wyka (1993).

W proponowanym przez nią modelu mamy do czynienia z założeniem podmiotowości badaczy i badanych (a zatem równym poziomem ontologicznym) a całość uzupełnia przedmiot badania, który stanowi problem badawczy. Tyle tylko, że proces badawczy nie jest $\mathrm{w}$ takim ujęciu podejmowany $\mathrm{z}$ zewnątrz, bowiem podstawowym założeniem metodologicznym jest tutaj badanie przez doświadczanie, czyli przedmiot badania (tutaj zjawisko kibicowania) jest przeżywane od środka. Trzecią cechą podejścia proponowanego przez Wykę jest podkreślenie wspólnoty, podzielanie eksplorowanego świata przez oba podmioty. Zbieżność naszej postawy z podejściem Anny Wyki nie od razu wydała nam się oczywista. Dopiero w toku badań zaczęliśmy dostrzegać, że nasza etnografia z pewnością nie jest etnografia wyzutą z przeżyć i solidnej dawki emocjonalnego zaangażowania $\mathrm{w}$ proces badawczy. Taki, nieco spóźniony, rodzaj refleksji nie jest słabością samych badaczy, bowiem czymś oczywistym w podejściu jakościowym jest pojawianie się pytań badawczych czy refleksji na temat sytuacji badawczej $\mathrm{w}$ trakcie samych badań. Nasze wyprawy badawcze zbliżyły się do podejścia alternatywnego (piszemy alternatywnego, choć wydaje się nam ono mainstreamowe, a nawet naturalne przy badaniu tego typu zjawisk) również dzięki temu, że obserwacje były cykliczne, a cykliczność jest istotnym elementem modelu badań przez wspólne doświadczanie (zob. Wyka 1993 58). W cyklach badacz zarówno „wchodzi” w przestrzeń badaną, jak i z niej „wychodzi”. Dzięki temu może nabrać powietrza, czyli zrewidować dotych- czasowe osiagnięcia, przemyśleć kolejne „zanurzenie", uporządkować fakty, a przede wszystkim próbować ocenić na ile jego podmiotowość uległa przekształceniom. Wspólne, zwłaszcza ekstremalne doświadczenia oraz doznania graniczne nie pozostawiają badacza obojętnym, ponieważ podczas eksploracji zjawisk terenowych wymuszają przeżycia niemalże całym sobą. Doświadczanie implikuje zawieszenie obiektywizującej postawy, co oznacza, że im silniejsze jest doświadczenie, tym trwalsze jest zawieszenie postawy. Dopuszczenie subiektywności przeżyć doprowadza w konsekwencji do „iniekcji" doświadczenia wspólnoty w świat wewnętrzny badacza. Tym samym pojawia się istotne pytanie: czy otwarcie się na doświadczanie ma konsekwencje dla przemiany badawczego Ja?

W naszym przekonaniu odpowiedź na to pytanie jest pozytywna. Przypomnijmy: opisywaliśmy wcześniej chwile „religijnego" uniesienia, jakim naszym zdaniem jest wspólnie doświadczany przedmeczowy taniec w rytm techno, nieartykułowane okrzyki wywołane przeraźliwym hukiem petard czy stadionowy śpiew kilkunastu tysięcy osób. Model badań przez doświadczanie nakazuje, by temu zbiorowemu uniesieniu dać się ponieść, po prostu je przeżyć. $W$ takim przypadku jest to dyrektywa słuszna, ponieważ kieruje umysł badacza w stronę esencji kibicowania. Stan ten jest porównywalny ze stanem excitement czy opisywanym przez Rolanda Barthesa jouissance (zob. 1997). W sensie psychologicznym grupowe doświadczaniejednej „wibracji” stanowi rodzaj wspólnotowego flow, czyli stanu zacierania się granic i otwierania się możliwości, które są niedostępne w chwilach kontrolowania swoich poczynań i chłodnego dystansu. To jest wreszcie stan liminalności, rodzaj „,bycia pomiędzy" (zob. Turner 1969). To jest ten rodzaj uniesienia, którego nie dostrzegaliśmy, analizując zjawisko kibicowania "z werandy", co praktykowaliśmy, konstruując założenia naszego projektu. Wydawaliśmy wtedy sądy o sporcie i kibicach, bazując na źródłach zastanych, cały czas - w imię obiektywizmu - oddzielając przedmiot badawczy od nas samych. Dopiero doświadczanie ukazało nam świat badanych w pełnej krasie.

Model badań przez doświadczanie aplikowaliśmy kilkukrotnie, co pozwoliło nam ciągle od nowa spoglądać na przeżywane sytuacje. Było to istotne zwłaszcza dla B2, dla którego badanie było pierwszym „zanurzeniem” w pełen uniesień, skrajnych doświadczeń i granicznych sytuacji kibicowski świat. Z prac Mihalyego Csíkszentmihályi o przepływie wiemy, że przeżywanie tego rodzaju stanów poszerza tożsamość jednostki (zob. 2005). Wiemy też od Victora Turnera, że liminalność to nie tylko stopień zawieszenia i stan „pomiędzy”, ale też specyficzny próg (stąd określenie threshold people), którego przekroczenie automatycznie wyznacza nowy status. Jak zatem doświadczenie "bycia pomiędzy" wpływa na badaczy? Dokąd idzie się po przekroczeniu „progu”? Odpowiedź może się wydać banalna: w pewien sposób „stubylczyliśmy się". Perspektywa industrialnych kibiców stała się nam bliższa, co w pracach dotyczących metodologii badań terenowych na ogół traktowane jest jako zagrożenie. Weźmy chociażby takie zdanie: „[r]adość uczestniczenia w grupie może nie tylko skłonić do porzucenia wszelkich obowiązków badawczych, ale z czasem spowodować zniekształcenia $\mathrm{w}$ dokonywanych ocenach $\mathrm{w}$ wyniku nadmiernego zżycia się z badanym środowiskiem" (Hammersley, Atkinson 2000: 118).

Trudno jednak uciec od emocji, są one integralną częścią tak specyficznego procesu badawczego, opartego na wytycznych wspólnotowego doświadczania. Weźmy dla przykładu nasz wyjazd na fi- 
nał Pucharu Holandii. Mecz zakończył się zwycięstwem Twente po rozgrywce pełnej ogromnych emocji i gwałtownych odmian losu. Ajax prowadził już 2:0. Twente najpierw wyrównało, a potem, przed końcem dogrywki, zdobyło decydującego gola. Końcowe minuty tego meczu były właściwie w całości wypełnione doświadczaniem kibicowskiej duszy zbiorowej, nieopisanej, spontanicznej radości czy wręcz ekstazy religijnej. Wspólnotowe doświadczanie spowodowało, że w drodze powrotnej, być może tylko wskutek sportowego zwycięstwa, ekstremalnego wypadu do centrum Rotterdamu, ale najpewniej w wyniku przekroczenia pewnego ",progu”, poczuliśmy się bardziej zjednoczeni i nasze Ja wydawały nam się bliższe Ja badanych. Głośna muzyka wydawała się nam mniej uciążliwa (inna sprawa, że upojenie zwycięstwem szło w parze z inną muzyką, dominowała stylistyka bardziej stonowana, z silną reprezentacją reggae Boba Marleya), czuliśmy się coraz bardziej swobodnie i można powiedzieć, że na swój sposób się zadomowiliśmy. Mamy wrażenie, że dopiero wspólnotowe doświadczanie urealnia i uprawomocnia postulat nadania podmiotowości obu stronom procesu badawczego.

Podsumowanie: mechanizm „podwójnej kotwicy"

Obserwacja uczestnicząca w środowisku kibiców umożliwiła nam doświadczenie społecznego fenomenu kibicowania, „zanurzenie się" w nim i wyjście poza dominujący w literaturze powierzchowny opis z pozycji „werandy”. Rodzi się przy tym kilka istotnych pytań metodologicznych. Po pierwsze, należy zapytać: kto ma rację? Czy nasze wnioski są bardziej zasadne tylko dlatego, że byliśmy bliżej? Jesteśmy skłonni odpowiedzieć twierdząco, choć $\mathrm{z}$ drugiej strony wyłania się uzasadniona wątpli- wość: czy bardziej rzetelny opis może być dziełem kogoś, kto uległ wspólnotowej przemianie? Czy rzetelny opis może zaproponować ktoś, kto doświadczył „uniesienia”? A jeżeli nawet, to jak przedstawić to „uniesienie” osobom, które nigdy go nie doświadczyły? Które nigdy nie zeszły „z werandy” i traktują kibiców jako agresywny tłum, który gardłuje swoje niecenzuralne i pełne epitetów przyśpiewki. Innymi słowy, do rozstrzygnięcia pozostaje istotna kwestia weryfikacji tego, co udało się ustalić na polu badawczym.

Istnieje kilka procedur weryfikacyjnych, których można w tym przypadku użyć. Rozwiązaniem, które postuluje Wyka, jest przyjęcie perspektywy zamiast opierania się na tradycyjnym podziale subiektywizm/obiektywizm. Perspektywą byłby tutaj „osobisty pogląd formułowany z pewnego dystansu" (Wyka 1993: 61), bez stronniczości wyłaniające się z subiektywizmu ani uniwersalności obiektywizmu. Wyka wskazuje cechy takiego dystansu, na które składałaby się wiedza badacza pochodząca z sytuacji badawczej, wiedza weryfikowana przez podmioty badania oraz wiedza teoretyczna badacza wzbogacana przez doświadczenia podmiotów badania (zob. 1993: 61-62). Propozycja ta sytuuje sie zatem między subiektywizmem a obiektywizmem, a inaczej - kieruje badacza w stronę wiedzy weryfikowanej intersubiektywnie. Decydujące są tu umiejętność samokontroli oraz interpersonalna wymiana wiedzy. Skorzystaliśmy z tej ostatniej tylko w minimalnym stopniu. To, czego doświadczyliśmy podczas przebywania we wspólnocie poruszane było w prywatnych rozmowach z kibicami i w wywiadach pogłębionych. Mamy oczywiście świadomość, że nie była to pełna weryfikacja ustaleń przez podmiot badany, jakim byli kibice. Być może zalecenie Wyki udałoby się zrealizować, gdybyśmy mie- li łatwiejszy dostep do siebie nawzajem, ale w tym przypadku odległość była skuteczną przeszkodą. Nie wiadomo także jak kibice odnieśliby się do naszych wniosków spisanych w języku angielskim, które musiałyby być przygotowane w przystępnej dla nich formie.

Znacznie bardziej dostępną formą weryfikacji była dla nas możliwość analizy ustaleń we własnym gronie, w ramach spotkań zespołu badawczego, zmierzająca do osiągnięcia większej trafności wewnętrznej - autentyczności czy wiarygodności opisu tak w naszych oczach, jak i w opinii osób czytających raport z badań (por. Miles i Huberman 2000). Bardzo ważnym elementem naszej obserwacji było to, że prowadzona była ona równolegle przez dwóch badaczy, z których jeden był bardziej zintegrowany ze wspólnotą, a drugi rozpoczynał badania jako osoba zupełnie nieznana badanym. Ten zabieg - pozornie bardzo prosty, ale $\mathrm{w}$ naszej opinii niezmiernie istotny - zapewniał pewien rodzaj intersubiektywności, a w rezultacie bardziej autentyczny i wiarygodny opis; skoro raport $\mathrm{z}$ badawczych przeżyć pisany był z dwóch, a nawet $\mathrm{z}$ trzech (kłania się tu kontrolna rola B3) punktów widzenia. Odmienny sposób definiowania sytuacji przez każdego z badaczy pozwalał na lepsze jej zrozumienie. Nietrudno odgadnąć, że każdy z nas przeżywał wydarzenia w toku eksploracji - ze względu na różnicę $\mathrm{w}$ stopniu zaangażowania - nieco inaczej, co mogliśmy na bieżąco ze sobą konfrontować. Analizy i próby dojścia do wzajemnego zrozumienia i wspólnej konstatacji zabrały nam sporo czasu w drodze powrotnej, a także już w kraju, gdy często kontaktowaliśmy się ze sobą w celu skonstruowania podsumowań oraz rozwiania wątpliwości. Oczywiście nie musi to gwarantować idealnej weryfikacji, ale $\mathrm{z}$ pewnością pomaga $\mathrm{w}$ przedstawieniu raportu o wysokim stopniu autentyczności/wiarygodności.
Gdybyśmy mieli wskazać metodologiczną wartość dodaną przeprowadzonego przez nas projektu stanowiłaby ją propozycja badań obserwacyjnych „w pełnym zanurzeniu” z kontrolnymi mechanizmami „kotwicznymi”, które zapobiegają „odpłynięciu" badacza wraz z badaną przez niego zbiorowością. Badania etnograficzne prowadzone we „wspólnotach integrujących” w atmosferze emocjonalnego uniesienia, a w skrajnych przypadkach nawet ekstazy religijnej, narażone są na niebezpieczeństwo nierzetelności przy zbieraniu materiału oraz jego późniejszej interpretacji. Stosowany przez nas mechanizm „podwójnej kotwicy” pozwala na prowadzenie badań „w pełnym zanurzeniu" bez obaw o nierzetelność procesu zbierania oraz analizy materiału badawczego. Pozycja i niższy stopień zaangażowania B2 stanowią pierwszy mechanizm „kotwiczny” w procesie gromadzenia danych przez B1 pozostającego w "pełnym zanurzeniu”. Natomiast B3 zapewnia drugi mechanizm "kotwiczny" gwarantujący rzetelną interpretację oraz późniejszą analizę. Zbiorowa dusza kibiców wraz z (niemal) namacalną durkheimowską solidarnością mechaniczną jest metodologicznie i etycznie niebezpieczna, niczym nurt rwącej, górskiej rzeki, który może nie robić większego wrażenia na obserwatorze zewnętrznym, a jednak potrafi z ogromną siłą porwać znajdujących się w wodzie badaczy. Dotyczy to przede wszystkim tego, który prowadzi obserwacje „W pełnym zanurzeniu", choć niebezpieczeństwo porwania przez nurt rzeki dotyczy również badacza, który dopiero zaczyna eksplorować teren. Sądzimy, że zastosowany przez nas mechanizm „podwójnej kotwicy" pozwolił uniknać pułapek związanych ze „stubylczeniem".

Pozostaje jeszcze ustalenie trafności zewnętrzne wyników naszych badań, czyli zakresu dopasowa- 
nia naszych ustaleń do kontekstu zewnętrznego. Sprowadza się to do pytania, na ile wyniki naszej eksploracji mogą być generalizowane na inne konteksty, na wszystkie grupy hardcorowych kibiców. Niestety pozostawimy to pytanie bez odpowiedzi, choćby dlatego, że wymagałoby to między innymi zastosowania procedury ustawicznego przechodzenia między perspektywami emic i etic, „,iągłego sprawdzianu trafności" (zob. Angrosino 2010: 130). Takie przechodzenie było $\mathrm{w}$ przypadku naszych badań zaburzone przez doświadczanie wspólnotowe. O ile niektóre z sytuacji, w których uczestniczyliśmy, umożliwiają takie przełączanie perspektyw (np. podróż na stadion, wyczekiwanie na kontrolę osobistą przed bramkami, konfrontacja naszych obserwacji z wiedzą ekspertów - kibiców, szefów klubów - preparowaną w trakcie wywiadów swobodnych itp.), to jednak doświadczenie, któremu się poddaliśmy, nie pomaga w realizacji tego rodzaju ciągłego sprawdzianu. Chwile liminalności w trakcie meczów skutecznie utrudniają przechodzenie

\section{Bibliografia}

Angrosino Michael (2010) Badania etnograficzne i obserwacyjne. Przełożyła Maja Brzozowska-Brywczyńska. Warszawa: Wydawnictwo Naukowe PWN.

Antonowicz Dominik, Kossakowski Radosław, Szlendak Tomasz (2011) Ostatni bastion antykonsumeryzmu? Kibice industrialni w dobie komercjalizacji sportu. „Studia Socjologiczne", nr 3 (202), s. 113-139.

Armstrong Gary (1993) Like that Desmond Morris? [w:] Dick Hobbs, Tim May, eds., Interpreting the Field: Accounts of Ethnography. Oxford: Clarendon, s. 3-39.

Barthes Roland (1997) Przyjemność tekstu. Przełożyła Adriana Lewańska. Warszawa: Wydawnictwo KR.

Becker Howard S. (1958) Problems of inference and proof in participant observation. „American Sociological Review”, vol. 23 , no. 6, s. 652-660. od perspektywy uczestnika do perspektywy zewnętrznego oceniającego, nawet post factum. Poza tym, aby dokonać przejścia między tymi światami, czyli między fenomenologią common sense a scientific rationality, trzeba najpierw dokładnie określić, gdzie owo przejście, gdzie ta granica się znajduje. Bardzo trudne było rozdzielenie roli badacza-obserwatora od badacza-uczestnika, a w konsekwencji trudno było o porównywalność naszych przeżyć z przeżyciami innych (autorów innych eksploracji świata kibicowskiego czy innych kibiców).

Przyznajemy tym samym, że pewne zadania okazały się bardzo trudne, być może nawet przerastające możliwości naszego warsztatu. Mamy jednocześnie nadzieję, że nasza próba stanie się tekstem otwartym do wykorzystania przez tych wszystkich, którzy zechcą pewnego dnia wyruszyć na eksplorację świata kibiców, a gdy im się to uda - zechcą samodzielnie sprawdzić adekwatność naszych ustaleń. Bardzo ciekawe, co wtedy napisza.

Becker Howard S. (2009) Outsiderzy. Studia z socjologii dewiacji. Przełożyła Olga Siara. Warszawa: Wydawnictwo Naukowe PWN

Csíkszentmihályi Mihály (2005) Przeptyw. Psychologia optymalnego doświadczenia. Przełożyła Magdalena WajdaKacmajor. Taszów: Biblioteka Moderatora.

Dudała Jerzy (2004) Fani-chuligani. Rzecz o polskich kibolach. Warszawa: Wydawnictwo Żak.

End Christian M. i in. (2003) Sport fans' attitudes towar war analogies as descriptors for sport. „Journal of Sport Behavior", vol. 26, no. 4, s. 356-367.

Giulianotti Richard (1995) Participant Observation and Research into Football Hooliganism: Reflections on the Problems of Entrée and Everyday Risks. „Sociology of Sport Journal”, vol. 12 , no. 1, s. $1-20$
Gizińska Katarzyna (2011) Motocyklistki. Socjologiczne spojrzenie na kobiety i stereotypy w motoświecie. „Ikonosfera”, $\mathrm{nr}$ 3 [dostęp 11 października 2012 r.]. Dostępny w Internecie http://www.ikonosfera.umk.pl/fileadmin/pliki/ikonosfera_3_Katarzyna_Gizinska_Motocyklistki.pdf .

Goffman Erving (2005) Piętno. Rozważania o zranionej tożsamości. Przełożyły Aleksandra Dzierżyńska, Joanna Tokarska-Bakir. Gdańsk: Gdańskie Wydawnictwo Psychologiczne.

Gold Raymond L. (1958) Roles in sociological field observations. „Social Forces”, vol. 36, no. 3, s. 217-223.

Hammersley Martyn, Atkinson Paul (2000) Metody badań terenowych. Przełożył Sławomir Dymczyk. Poznań: Zysk i S-ka.

Hughson John, Inglis David, Free Marcus (2005) The Uses of Sport. A Critical Study. Abingdon: Routledge.

Konecki Krzysztof T. (2010) W stronę socjologii jakościowej: badanie kultur, subkultur i światów spotecznych [w:] Jacek Leoński, Magdalena Fiternicka-Gorzko, red., Kultury, subkultury $i$ światy społeczne w badaniach jakościowych. Szczecin: Volumina.pl, s. 17-37.
Kossakowski Radosław, Antonowicz Dominik, Szlendak Tomasz (w druku) Pitkarz jako marka i peryferyjny kibic jako aborygen. O wybranych społecznych konsekwencjach komercjalizacji sportu. „, Kultura i Społeczeństwo”, nr 3.

Lemert Edwin (1967) Human Deviance, Social Problems and Social Control. New York: Prentice-Hall.

Miles Matthew B, Huberman Michael A. (2000) Analiza danych jakościowych. Przełożył Stanisław Zabielski. Białystok: Wydawnictwo Trans Humana.

Park Robert (1928) Human migration and the marginal man. „The American Journal of Sociology”, vol. 23, no. 6 s. $881-893$.

Sahaj Tomasz (2007) Fani futbolowi. Historyczno-spoteczne studium zjawiska kibicowania. Poznań: AWF.

Simmel Georg (2006) Most i drzwi. Wybór esejów. Przełożyła Maria Łukasiewicz. Warszawa: Oficyna Naukowa.

Turner Victor W. (1969) The Ritual Process: Structure and Anti-Structure. Chicago: Aldine.

Wyka Anna (1993) Badacz spoteczny wobec doświadczenia. Warszawa: IFiS PAN. Cytowanie
Kossakowski Radosław, Antonowicz Dominik, Szlendak Tomasz (2012) Duszacy dym odpalonych rac. O wyzwaniach
w etnografii subkultury kibiców pitkarskich. "Przegląd Socjologii Jakościowej”, t. 8, nr 3, s. 6-29 [dostęp dzien, miesiąc,
rok]. Dostępny w Internecie: http://www.przegladsocjologijakosciowej.org.

\section{Choking Smoke of Burning Flares. On Challenges to Ethnography of Football Fans Subculture}

The paper explores a wide range of ethnographic challenges - risky situations, methodological dilemmas, ethical and logistic problems - that we encountered in our field research on most devoted fans of FC Twente Enschede. The analysis is focused on the variety of issues that come along with the process of exploration of largely closed communities of hardcore fans. By doing so, we want to provide some guidelines for those researchers who would want to undertake similar adventures ethnographic tasks in the future. The paper is centered around four major issues. The first one refers to the access to the hermetic world of football fans, while the second section is devoted to the different types of dangers that are linked with experiencing football fandom in the match day. The third one are the consequences of such radical ethnography for the identity of the researcher, resulting from carrying out the research in the mode of "complete immersion." The fourth issue is the influence of the first three problems (gaining access to a closed group, dangers of full involvement in the actions of a group and changes within the identity of the "immersed one") on the inner accuracy and outer integrity of the ethnographic description.

Key words: football fans, participant observation, experiencing, liminality 